\title{
WORKSHOP PENYUSUNAN KARYA TULIS ILMIAH (KTI) BAGI WIDYAISWARA BPSDM PROPINSI NTB
}

\author{
Rahmawati $^{1 *}$, Muti'ah ${ }^{1}$, dan Syarifa Wahidah Al Idrus ${ }^{1}$ \\ ${ }^{1}$ Program Studi Pendidikan Kimia, Universitas Mataram, Mataram, Indonesia. \\ * Coressponding Author. E-mail: rahmawati_kimia@unram.ac.id
}

\begin{abstract}
Abstrak
Widyaiswara pada kantor BPSDM NTB mempunyai tugas pokok mempublikasikan karya tulis ilmiah sebagai salah satu syarat mendapatkan angka kredit untuk kenaikan pangkat fungsional. Keterbatasan kemampuan menulis KTI menyebabkan widyaiswara kesulitan untuk melakukan publikasi. Workshop ini diselenggarakan untuk melatih widyaiswara menyusun karya tulis ilmiah untuk dipublikasikan pada seminar atau jurnal yang sesuai. Hasil workshop menunjukkan atusias para widyaiswara mengikuti kegiatan dan bersemangat melakukan penulisan. Tulisan yang telah atau masih dalam bentuk draft didampingi penulisannya sampai menjadi tulisan yang layak dan siap submit. Tindak lanjut dari kegiatan workshop ini adalah pendampingan penulisan yang menghasilkan: satu tulisan siap submit pada jurnal JSEH milik LPPM Unram, 1 jurnal lainnya telah submit pada jurnal Bestari milik BPSDM NTB, 1 draft tulisan yang disajikan pada sminar penjenjangan intern BPSDM, dan 1 tulisan telah diseminarkan pada Semnas Saintek LPPM Nopember 2020.
\end{abstract}

Kata Kunci: workshop, KTI, Widyaiswara

\section{PENDAHULUAN}

Jabatan fungsional widyaiswara adalah jabatan yang mempunyai ruang lingkup tugas, tanggung jawab, wewenang, dan hak untuk melakukan kegiatan mendidik, mengajar, dan melatih PNS (Permenpan RB nomer 22 tahun 2014 tentang jabatan fungsional widyaiswara dan angka kreditnya). Rumpun jabatan fungsional widyaiswara termasuk dalam rumpun pendidikan lainnya, kedudukan jabatan fungsional widyaiswa adalah PNS yang diangkat sebagai pejabat fungsional di bidang kediklatan pada lembaga Diklat Pemerintah yang dalam melaksanakan tugasnya harus memperoleh surat penugasan atau surat perintah dari pimpinan lembaga Diklat pemerintah yang bersangkutan. Tugas pokok widyaiswara adalah melaksanakan Dikjartih (pendidikan, pengajaran, pelatihan) PNS, evaluasi dan pengembangan Diklat pada lembaga Diklat pemerintah.

Kompetensi widyaiswara adalah pemilikan pengetahuan, keterampilan, dan kemampuan yang dituntut oleh Jabatan Fungsional Widyaiswara yang meliputi: kompetensi pengelolaan pembelajaran, substansi, kepribadian, dan sosial. Jabatan fungsional widyaiswara merupakan jabatan fungsional keahlian dengan urutan jenjang: widyaiswara ahli pertama (jenjang terendah), widyaiswara ahli muda, widyaiswara ahli madya, dan widyaiswara ahli utama (jenjang tertinggi). Salah satu sub unsur pada unsur utama kegiatan jabatan fungsional widyaiswara yang dinilai angka kreditnya adalah pengembangan profesi, yakni Pembuatan karya tulis atau karya ilmiah dalam bidang spesialisasi keahliannya dan lingkup kediklatan

Hasil wawancara dengan para widyaiswara di lapangan mengungkapkan satu kelemahan para WI, yakni kurangnya minat dan kemampuan sebagian besar dari mereka dalam menulis artikel ilmiah. Kelemahan tersbut disebabkan karena kesulitan pada saat membuat tulisan dan untuk mempublikasikannya, juga kesulitan untuk menentukan topik, mengawali suatu tulisan, dan mengembangkannya dalam bentuk tulisan yang padu.

Permasalahan yang dihadapi widyaiswara BPSDM Daerah Provinsi NTB dalam hal menulis artikel adalah: Keterampilan menulis artikel ilmiah serta keterampilan dalam melakukan penelitian yang hasilnya bisa dipublikasikan dalam bentuk artikel ilmiah belum memadai. Maka solusi yang dilakukan adalah memberikan 
pelatihan penyusunan artikel ilmiah bagi para widyaiswara di lingkup BPSDM daerah provinsi NTB untuk memenuhi tuntutan jumlah angka kredit sebagai bagian dari persyaratan pengusulan kenaikan jabatan fungsional.

\section{METODE PELAKSANAAN}

Kegiatan Pelatihan Penulisan artikel ilmiah dilakukan dengan metode:

1. Webinar secara online atau daring via Zoom Meeting.

2. Unjuk kerja secara klasikal.

3. Pendampingan, dilakukan melalui media Whatsapp, email, dan tatap muka langsung.

\section{HASIL KEGIATAN}

Kegiatan PKM ini mengundang seluruh Widyaiswara dan manajemen bagian diklat kantor BPSDM Propinsi NTB, dengan surat tugas terlampir, berjumlah 45 peserta. Kegiatan workshop berlangsung dalam 3 tahapan: seminar KTI di hari pertama, unjuk kerja di hari kedua, dan pendampingan konsultasi menulis artikel template sesuai pubikasi tujuan di hari ketiga dan seterusnya sampai tulisa siap untuk submit.

1. Pada kegiatan webinar di hari pertama peserta diberikan materi tentang bagaimana sistimatika penulisan karya ilmiah untuk diterbitkan pada jurnal, prosiding, atau seminar. Memberikan pengetahuan kepada peserta mengenai jurnal dan pengindeksan atau perangkingan baik jurnal intrnasional maupun jurnal nasional. Mengenalkan kepada peserta jurnal-jurnal yang dapat dimasuki oleh peserta sesuai tema tulisan. Secara rinci tema-tema materi pada seminar penulisan KTI dijelaskan pada Gambar 1.

2. Workshop penulisan karya ilmiah. Pada kegiatan ini peserta mempresentasikan draft tulisan yang diminta di hari pertama. Hasil presentasi peserta didiskusikan dan diberi masukan yang membangun agar hasil tulisan sesuai dengan jurnal/seminar yang dituju.

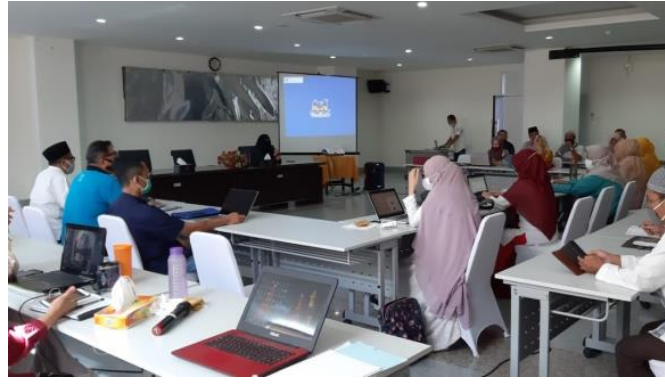

a

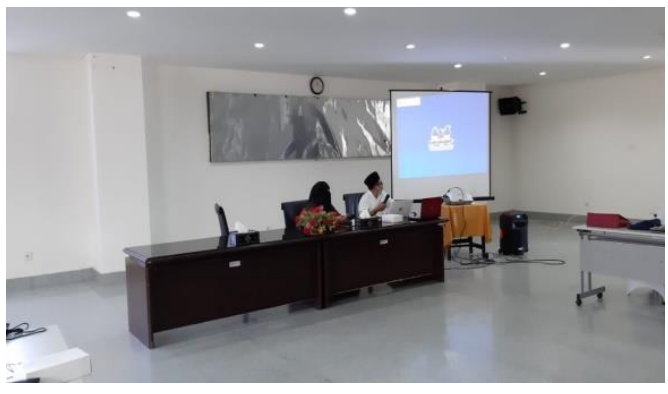

b

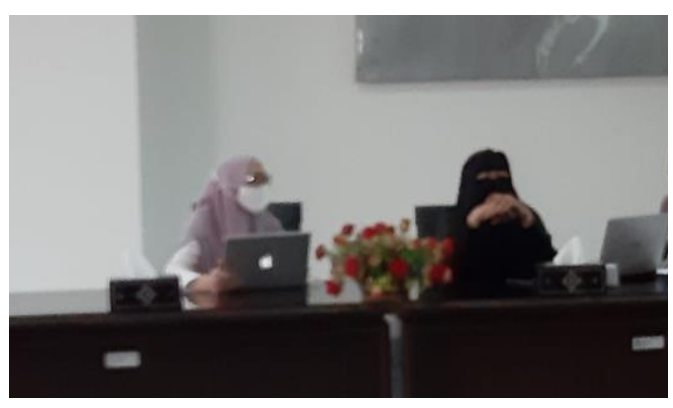

c

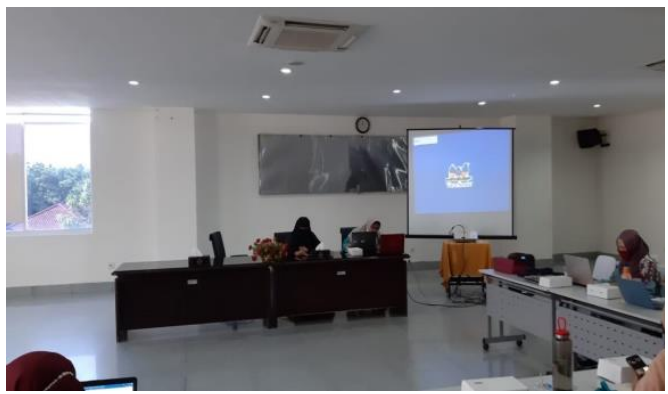

d 
Jurnal Pengabdian Inovasi Masyarakat Indonesia, 1 (1), 2022 - 25

Rahmawati, Muti'ah, Al Idrus

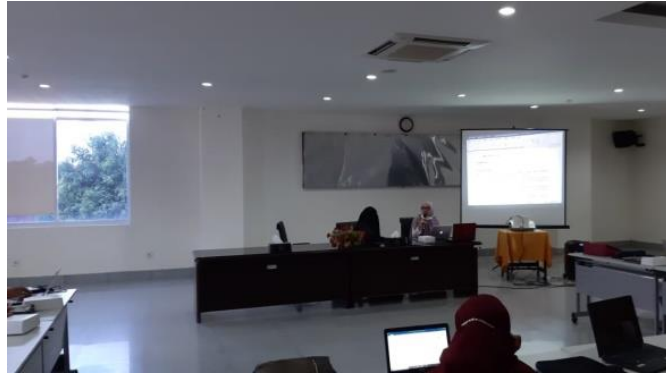

e

Gambar 3. Foto-foto kegiatan workshop. Gambar a memperlihatkan penyampaian materi pengabdian kepada peserta, yakni tentang penyusunan karya tulis ilmiah. Peserta antusias untuk menyimak uraian materi yang disampaiakan karena pada sesi pertama kegiatan seminar daring peserta telah diminta untuk mempersiapkan draft yang akan dibahas pada sesi unjuk kerja. Gambar b., c., dan d., memperlihatkan peserta-peserta workshop yang mempresentasikan draft tulisannya untuk dikomentari dan didiskusikan hal-hal yang perlu diambil sebagai masukan untuk perbaikan tulisannya.

3. Konsultasi dan pendampingan melalui media chatting WA dan email dilakukan pada harihari selanjutnya, dimulai pada hari ketiga. Prosedurnya, peserta didampingi secara offline di kantor BPSDM sampai draft siap untuk dikirim ke jurnal atau siap untuk diseminarkan. Sebagian lagi yang belum bisa menyelesaikan draft nya didamingi melalui media email. Berikut screen shoot dari pendampingan via WA dan Email ditunjukkan pada gambar 4 .
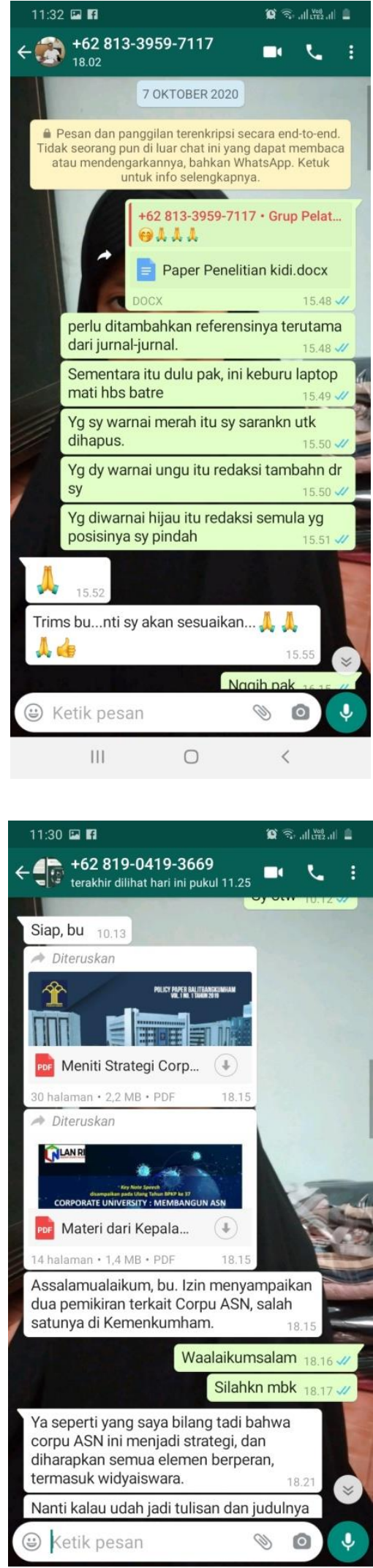
Jurnal Pengabdian Inovasi Masyarakat Indonesia, 1 (1), 2022 - 26

Rahmawati, Muti'ah, Al Idrus
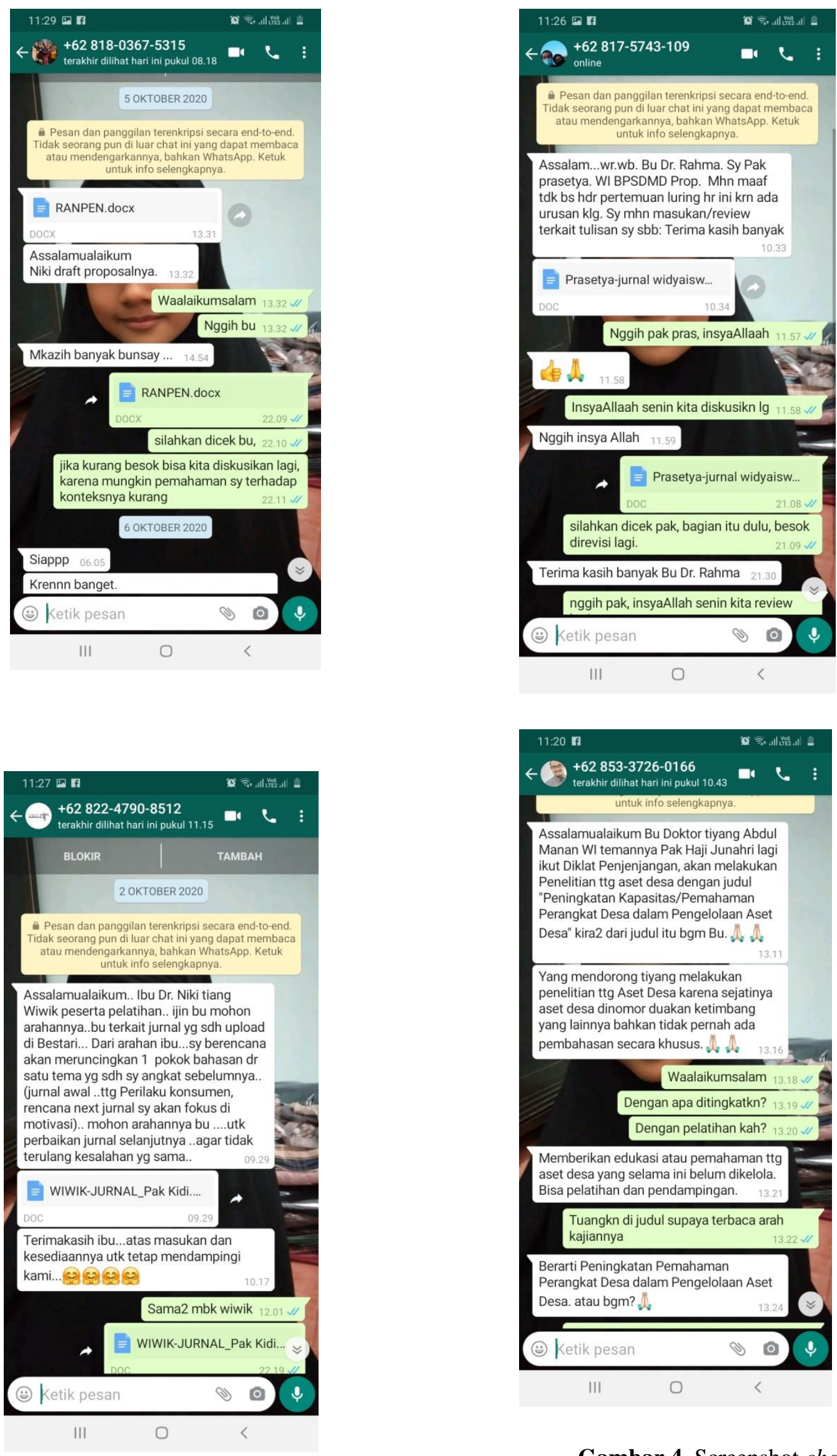

Gambar 4. Screenshot chatting WA pendampingan konsultasi KTI

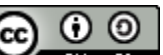

Jurnal Pengabdian Inovasi Masyarakat Indonesia is licensed under a Creative Commons Attribution-ShareAlike 4.0 International License 
Pada gambar 4 terlihat bagaimana antusiasnya peserta untuk membuat karya tulis yang bagus dan layak dimuat pada jurnal terakreditasi. Arah konsultasi menuju pada dihasilkannya karya tulis berbentuk jurnal yang siap submit ke jurnal. Dikarenakan BPSDM sedang merintis jurnal intrernal bernama 'Jurnal Bestari' maka pendampingan penulisan dikawal sesuai template jurnal tujuan.

Beberapa tulisan ilmiah yang didiskusikan pada sesi pendampingan konsultasi telah diterbitkan pada jurnal Bestari seperti artikel perilaku konsumen wista di era pandemi yang ditulis oleh Wiwik Suprihatin (2020), artikel tentang pengembangan kompetensi widyaiswara oleh Nurhikmah (2020), dan artikel penerapan prinsip good governance tulisan dari Haeli (2020).

\section{KESIMPULAN DAN SARAN}

Kesimpulan yang dapat diambil dari kegiatan workshop ini adalah: widyaiswara pada kantor BPSDM Propvinsi NTB sangat membutuhkan kemampuan untuk menulis karya ilmiah melalui kegiatan pelatihan atau workshop.

\section{UCAPAN TERIMAKASIH}

Pelaksanaan kegiatan pengabdian ini didanai dari PNBP internal Universistas Mataram dengan kontrak nomor 1927/UN18/LPPM/2020.

\section{DAFTAR PUSTAKA}

Wiwik Suprihatin, 2020, Analisis Perilaku Konsumben Wisatawan Era Pandemic
Covid-19 (Studi Kasus Pariwisata Di Nusa Tenggara Barat), jurnal bestari, 1,1, 56-66.

Haeli, 2020, Penerapan Prinsip-Prinsip Good Governance Pada Pemerintah Daerah Provinsi Nusa Tenggara Barat (Studi Kasus), jurnal bestari, 2020, 1,1, 1-9.

Nurhikmah, Community of Practices Sebagai Forum Pengembangan Kompetensi Widyaiswara Di Era Digital, 2020, 1,1, 1021.

Permenpan RB nomer 22 tahun 2014 tentang jabatan fungsional widyaiswara dan angka kreditnya, akses dari http://jdih.menpan.go.id/data_puu/Permen \%202\%20PHPI.pdf 28 Februari 2020.

Arikunto, S. 2002. Metodologi Penelitian Suatu Pendekatan Proposal. Jakarta: PT. Rineka Cipta.

Arikunto, S., (2010). Prosedur Penelitian Suatu Pendekatan Praktik. Penerbit Rineka Cipta. Jakarta.

Suroso, 2007, panduan penulisan artikel dan jurnal, akses dari https://opac.perpusnas.go.id/DetailOpac.a $\underline{\mathrm{spx} ? \mathrm{id}=103213}$, 29 Februari 2020.

Daftar Jurnal Terinex Inter dan Nasional, akses dari laman https://nazroel.id/2020/05/29/daftarjurnal-internasional-dari-indonesiaterindeks-scopus-per-mei-2020/, Februari 2020.

Purnomo,

akses dari https://media.neliti.com/media/publication s/210251-metodedan-teknikpengumpulan-data-dalam.pdf , 29 Februari 2020. 